\title{
Dietary phyto-oestrogens and bone health
}

\author{
Francesco Branca \\ Istituto Nazionale di Ricerca per gli Alimenti e la Nutrizione (INRAN), Via Ardeatina 546, 00178 Rome, Italy
}

\begin{abstract}
The use of dietary phyto-oestrogens as a possible option for the prevention of osteoporosis has raised considerable interest because of the increased concern about the risks associated with the use of hormone-replacement therapy. However, the evidence in support of a bone-sparing effect in post-menopausal women is still not sufficiently convincing. Most studies have been performed on soyabean isoflavones (genistein and daidzein), either in the purified form or as a soyabeanbased product or extract. In vitro studies using primary cell cultures or stabilised cell lines indicate that treatment with genistein may lead to a reduction in bone resorption, but effects on bone formation have also been shown. Investigations using animal models have provided convincing evidence of major improvements in bone mass or bone turnover following soyabean feeding. Cross-sectional observations in South-East Asian populations with moderately high intakes of soyabean isoflavones $(50 \mathrm{mg} / \mathrm{d})$ have shown that women in the high quartile of intake have higher bone mineral density (BMD) and reduced bone turnover, an effect that has not been shown in populations with low average intakes. Human trials have given an indication of a possible effect on lumbar spine BMD, although they have been either short term ( $<6$ months) or methodologically weak. Unresolved issues are: the optimal dose compatible with safety; the individual differences in response that can be related to diet and genotypes; the duration of exposure. Furthermore, there needs to be an evaluation of the relative biological effects of phytooestrogens other than isoflavones (lignans, resorcylic acid lactones, flavanols, coumestans) that are also present in European diets.
\end{abstract}

\section{Phyto-oestrogens: Osteoporosis: Soyabean}

The increase in life expectancy has led to bone health becoming a major concern. Femur or vertebral fractures are likely events that may severely affect the quality of life of the elderly. Hormone-replacement therapies (HRT) have been the first choice for treatment of hormone-related osteoporosis, but they have major side effects that preclude their universal use: uterine bleeding and hyperplasia; cardiovascular disease; gall bladder disease; oestrogen-induced endometrial cancer; increase in the risk of breast cancer. Since the Writing Group for the Women's Health Initiative Investigators (2002) observed a $15 \%$ increase in invasive breast cancer in women taking oestrogen plus progestogen for $<5$ years and a $53 \%$ increase in those taking it for $>5$ years, suitable alternatives have been sought.

The observation that South-East Asian women (Hong Kong, Indonesia, Korea, Malaysia, the Philippines, Singapore and Taiwan) report lower occurrence of hot flushes and sweating has led to the hypothesis that a protective role might be played by dietary factors, particularly soyabean phyto-oestrogens (Eden, 1998). In those countries a lower prevalence of chronic diseases such as cardiovascular disease, breast cancer and osteoporosis has also been observed. Thus, the use of dietary phytooestrogens has been considered as a possible option for the prevention of osteoporosis and, in view of their perceived natural origin, this approach is receiving considerable public attention. However, while many scientific panels have now reached a consensus on the effect of phyto-oestrogens on cardiovascular disease prevention, the same conclusion has not been reached for osteoporosis.

The purpose of the present review is to describe the rationale for the biological effects of phyto-oestrogens on bone and to analyse the evidence from in vitro and in vivo studies in animals and human subjects.

\section{Chemical structure and presence in food}

Phyto-oestrogen is a general definition that has been applied to '... any plant substance or metabolite that induces biological responses in vertebrates and can mimic or

\footnotetext{
Abbreviations: BMD, bone mineral density; ER, oestrogen receptor; FFQ, food-frequency questionnaire; HRT, hormone-replacement therapy; IGF insulinlike growth factor; RCT, randomised controlled trial.

Corresponding author: Professor Francesco Branca, fax +39 0651494 550, email F.Branca@agora.it
} 
modulate the actions of endogenous oestrogens usually by binding to oestrogen receptors' (Food Standards Agency, 2002). Three main classes have been identified: flavonoids; lignans; coumestans. A fourth class, resorcylic acid lactones, should also be added, although they are less relevant for human nutrition. The main compound is in fact zearalenone, which is synthesised by Fusarium moulds that develop during long-term storage of maize and is regarded as a contaminant. The common characteristic of these four classes is that they are diphenolic compounds with structural similarities to natural and synthetic oestrogens and antioestrogens (an aromatic A ring with one hydroxyl group and a second hydroxyl group on the same plane of the A ring; Fig. 1). Phyto-oestrogens are present in food both as aglycones and glucosides.
The main phyto-oestrogens currently recognised are soya-bean isoflavones, mainly genistein, daidzein and glycitein (mainly contained in soyabean germ) and their glycosides (genistin, daidzin, glycitin). The oestrogenic properties of other flavonoids present in marked amounts in several plant products have also been recognised: flavonols, e.g. quercetin and its glycosylated derivative rutin (quercetin-3-O-glucose rhamnose) widely present in vegetables such as onions or apples; flavanols, e.g. luteolin and apigenin contained in black olives; flavanones, e.g. hesperetin and naringenin contained in red oranges. Lignans (lariciresinol, isolariciresinol, secoisolariciresinol, matairesinol) are mainly present in wholemeal cereals, linseed and wild berries (Mazur et al. 2000).<smiles>Oc1ccc2c(c1)CCC1C2CCC2(O)C(O)CCC12</smiles>

Resorcylic acid lactones<smiles>CO[C@@H](C)CCCC(=O)CCC/C=C/c1cc(O)cc(O)c1C(=O)O</smiles>

Flavonols<smiles>Cc1cc(-c2oc3cc(O)cc(O)c3c(=O)c2O)cc(C)c1O</smiles>

Catechins<smiles>Cc1cc([C@@H]2Oc3cc(O)cc(O)c3C[C@H]2CO)cc(C)c1C</smiles>

Isoflavones<smiles>O=c1c(-c2ccc(O)cc2)coc2cc(O)ccc12</smiles>

Lignans<smiles>O=C1COCC(Cc2cccc(O)c2)C1Cc1cccc(O)c1</smiles>

Coumestans<smiles>Cc1cc(O)ccc1C1C(=O)Oc2cc(O)ccc2C1CO</smiles>

Flavanones<smiles>Cc1cc(C2CC(=O)c3c(O)cc(O)cc3O2)cc(C)c1O</smiles>

Anthocyanidins<smiles>Cc1cc(-[c+]2[cH-]c3cc(O)cc(O)c3cc2O)cc(C)c1O</smiles>

Fig. 1. Chemical structures of the four major classes of phyto-oestrogens, compared with those of the oestrogens and four additional classes of flavonoids commonly present in food. Isoflavones (e.g. genistein, daidzein, glycitein, formononetin, biochanin A) are present in soyabeans, chick peas and lentils. Lignans (e.g. lariciresinol, isolariciresinol, secoisolariciresinol, matairesinol) are present in wholemeal cereals, linseed and wild berries. Resorcylic acid lactones (e.g. zearalenone) are present in maize contaminated by Fusarium moulds. Coumestans (e.g. coumestrol) are present in young sprouting legumes, clover (Trifolium spp.) and lucerne (Medicago sativa) sprouts. Flavonols (e.g. quercetin, myricetin, kaempferol) are present in onions, broccoli, fennel, apples and cherries. Flavanones (e.g. naringenin, hesperidin) are present in citrus fruits and prunes. Flavones (e.g. apigenin, luteolin) are present in parsley, celery and black olives. Catechins (e.g. epicatechin, gallocatechin) are present in tea, apples and cocoa. Anthocyanidins (e.g. pelargonidin, malvidin, cyanidin) are present in cherries and grapes (Ross \& Kasum, 2002). 


\section{Absorption}

Absorption of isoflavones requires hydrolysis of the sugar moiety by intestinal $\beta$-glucosidase (Setchell et al. 2002b). Aglycones are then absorbed by diffusion through the enterocyte and across the intestinal wall. They undergo an extensive phase II metabolism (mainly glucuronidation and sulfation) both in the upper small intestine (gastrointestinal mucosa) and in the liver (Setchell et al. 1998). Deconjugation takes place at the level of the target tissue (Rowland et al. 2003). Absorption is very rapid; plasma isoflavones are detected at 15-30 min post-ingestion and reach a peak at between 3 and $7 \mathrm{~h}$. Lignans are absorbed more slowly; they appear in plasma at approximately $8.5 \mathrm{~h}$ post-ingestion (Morton et al. 1997).

\section{Effects of phyto-oestrogens at the molecular level}

The effects of phyto-oestrogens are related not only to the interaction with the oestrogen receptors (ER), but also to other actions not mediated by the ER in a similar fashion to oestrogens. Hall et al. (2001) indicate that, in addition to the classical ligand-dependent action, there are three nonclassical actions: ligand-independent; DNA bindingindependent; cell-surface (non-genomic) signalling. The non-classical actions seem particularly important in explaining the selective action of phyto-oestrogens on bone.

The classical action is dependent on the binding of oestrogens with ER, which are ligand-activated nuclear transcription factors, members of the nuclear receptor family of transcription factors. Two different ER have been described, ER $\alpha$ and ER $\beta$, which differ in both their ligand-binding properties (C-terminal domain) and their transactivation activity (N-terminal domain). Up to five isoforms have been detected for each receptor (Nilsson et al. 2001). Different tissues have different proportions of the two receptors, with a predominance of ER $\alpha$ in reproductive system tissues (Food Standards Agency, 2003). Both receptors are present in bone tissue. Cells of osteoblastic origin express both $\mathrm{ER} \alpha$ (Braidman et al. 1995) and ER $\beta$ (Braidman et al. 2001). Preosteoclasts express ER $\alpha$, but $\mathrm{ER} \alpha$ expression is lost during osteoclast maturation (Oreffo et al. 1999). Indirect immuno-peroxidase staining of fracture callus biopsies has shown that expression of ER $\alpha$ and $\operatorname{ER} \beta$ is similar for all cells in males and females $<40$ years of age, but there is a decreased proportion of osteocytes expressing $\mathrm{ER} \alpha$ and $\mathrm{ER} \beta$ proteins in women $>40$ years of age (Batra et al. 2003). In addition, three ERrelated receptors, formerly termed 'orphan' receptors, have been described, but only one of them (ER-related receptor $\alpha$ ) has been identified in osteoblastic cells and in osteoclasts in vivo and in vitro (Bonnelye et al. 2002). The two ER signal in different ways depending on both ligand and response element activities (Paech et al. 1997). Binding with different compounds induces different conformational changes in the ER. Thus, phyto-oestrogens can act as pure agonists, as partial agonists or as pure antagonists. For example, genistein binds to ER $\beta$ in the same way as $17 \beta$ oestradiol, but the transactivation helix adopts a different position such that the action is that of a partial agonist (Pike et al. 1999). ER $\alpha$ and ER $\beta$ can form homodimers or heterodimers with different transcription activities. ER $\alpha$ homodimers have a higher transcription activity than ER $\beta$ homodimers, while the heterodimers have a transcription activity intermediate between those of the $\alpha / \alpha$ and $\beta / \beta$ homodimers. The presence of different proportions of $\alpha$ and $\beta$ receptors may lead to different combinations and this factor could also explain the tissue differences in their action.

As far as the non-classical actions are concerned, the ligand-independent action involves growth factors, such as insulin-like growth factor (IGF) 1 . The modification of the phosphorylation state of the ER by cellular kinases may serve as an important mechanism of ligand-independent activation (Hall et al. 2001). The cell-surface (non-genomic) signalling involves regulation of enzymes implicated in signal transduction, such as protein tyrosine kinase, mitogen-activated protein kinase and inhibition of DNA topoisomerase II. In human mammary epithelial cells genistein has been shown to inhibit cell proliferation through the p38 mitogen-activated protein kinase pathway (Frey \& Singletary, 2003). Phytooestrogens may also act through the phosphatidyl inositol-3 kinase or serine/threonine protein kinase pathways. Phosphoserine/threonine protein kinase is also localised in the nucleus of cultured cardiomyocytes after exposure to $17 \beta$-oestradiol or genistein (Camper-Kirby et al. 2001).

Finally, phyto-oestrogens can also modulate the action of endogenous oestrogens through the regulation of ER expression and the metabolism and bioavailability of oestrogens. Pharmacological, but not physiological, concentrations of genistein can modulate sex steroid receptor expression in the rat uterus (Cotroneo et al. 2001). In vitro phyto-oestrogens inhibit the formation of $17 \beta-\left[{ }^{3} \mathrm{H}\right]$ oestradiol from $\left[{ }^{3} \mathrm{H}\right]$ androstenedione, although this activity has not been confirmed in vivo (Saarinen et al. 2001). A study in post-menopausal women indicated that a diet rich in phytooestrogens and complex carbohydrates was associated with a $25 \%$ increase in sex hormone-binding globulin in the intervention group (Berrino et al. 2001).

The oestrogenic potency of the different compounds has been measured in competitive-binding assays, in which the relative binding affinity for $\operatorname{ER} \alpha$ and $\operatorname{ER} \beta$ is measured, as well as in transactivation assays. If the former is used (Kuiper et al. 1997) the affinity for $\mathrm{ER} \alpha$ is $\mathrm{E} 2>>$ coumestrol $>$ zearalenone $>>$ genistein $>$ daidzein and the affinity for $\operatorname{ER} \beta$ is E2=coumestrol $>>$ zearalenone $>$ genistein $>>$ apigenin $=$ kaemperol $>$ daidzein $>>$ naringenin. If instead a transactivation assay is carried out, then for $\mathrm{ER} \alpha \mathrm{E} 2>>$ zearalenone $=$ coumestrol $>$ genistein $>$ apigenin $=$ phloretin $>$ biochanin $\mathrm{A}=$ kaempferol=naringenin $>$ formononetin $=$ ipriflavone $=$ quercetin $=$ chrysin and for $E R \beta E 2>>$ genistein $=$ coumestrol $>$ zearalenone $>$ daidzein $>$ biochanin $A=$ apigenin $=$ kaempferol $=$ naringenin $>$ phloretin $=$ ipriflavone $=$ quercetin $=$ chrysin.

The proliferation of several cell systems has also been used to compare the different phyto-oestrogen compounds. In a proliferation assay that used MCF-7 cells coumestrol, daidzein, luteolin and quercetin exerted a proliferationstimulating activity as strong as that of oestradiol, but they suppressed the induction of the proliferation-stimulating activity of environmental oestrogens (Han et al. 2002). An in vitro assay that used BT-474 human breast cancer cells 
demonstrated that biochanin A and genistein had the most potent oestrogenic activity. Of the other flavonoids, luteolin and naringenin displayed the strongest oestrogenicity, while apigenin had a relatively strong progestinic activity (Zand et al. 2000).

In conclusion, the action of phyto-oestrogens varies according to the type, combination and concentration of compounds, the type of tissue and factors affecting ER presence, such as age. Phyto-oestrogens have a role as partial agonists, as they may also inhibit the action of oestrogens. Finally, androgenic and progestinic effects should also be considered in addition to the oestrogenic effects. Thus, it would probably be more appropriate to refer to these compounds as selective oestrogen receptor modulators of plant origin.

\section{Effects of phyto-oestrogens on bone cells}

Genistein is the phyto-oestrogen that has been most investigated for its effect on the proliferation and differentiation of a number of cell types. Through its effect on tyrosine kinase, genistein is able to modulate cell cycle progression in the $S$ phase, to induce G2/M arrest and to induce apoptosis (Matsukawa et al. 1993). Genistein is also able to inhibit the growth of breast cancer cell lines (Lamartiniere et al. 2002), to inhibit angiogenesis (Fotsis et al. 1993) and to modulate lymphocyte activation and proliferation (Guo et al. 2001).

Specific effects on bone cells have been shown both in osteoblasts and osteoclasts. In osteoblasts genistein stimulates a concentration-dependent increase in alkaline phosphatase activity. In osteoblastic MC3T3-E1 cells genistein or daidzein at concentrations of $10^{-7}-10^{-5} \mathrm{M}$ increase protein content, DNA content and alkaline phosphatase activity (Yamaguchi \& Sugimoto, 2000). This effect has also been demonstrated in tissue cultures. In femoral metaphyseal tissue from elderly female rats genistein $\left(10^{-6}-10^{-5} \mathrm{M}\right)$ increases $\mathrm{Ca}$ content and alkaline phosphatase activity. This increase is blocked by tamoxifen, indicating an ER-mediated pathway, and also by cycloheximide, suggesting it is mediated by overall increased protein synthesis (Yamaguchi \& Gao, 1997, 1998). On the other hand, genistein can also cause apoptosis of osteoblasts by activating caspase- 3 and cleaving adhesion molecules such as cadherins and catenins (Hunter et al. 2001). In normal fetal osteoblast cells genistein increases the progesterone receptor and alkaline phosphatase gene expression and inhibits osteopontin and interleukin 6 gene expression (Rickard et al. 2003).

In osteoclasts an effect has been observed on osteoclast differentiation as well as function. Genistein reduces osteoclast differentiation from pre-osteoclasts via non-ER-related signalling pathways. Gao \& Yamaguchi (1999) observed that genistein is able to reduce the formation of osteoclastlike mononuclear cells induced by dibutyryl cAMP (cAMP pathway), but not the formation of mononuclear cells induced by phorbol 12-myristate 13-acetate (protein kinase $\mathrm{C}$ pathway). Phyto-oestrogens may also act on osteoclast production through inhibition of macrophage colonystimulating factor (Srivastava et al. 1998). Hughes et al. (1996) showed that oestrogens cause osteoclasts to undergo apoptosis through increased production of transforming growth factor- $\beta 1$ by osteoblasts. In porcine bone marrow cells daidzein was able to reduce 1,25dihydroxycholecalciferol-stimulated osteoclast formation in vitro, promote caspase- 8 and caspase- 3 cleavage and DNA fragmentation of monocytic bone marrow cells and reduce the area resorbed by mature osteoclasts (Rassi et al. 2002). Lieberherr et al. (2003) have put forward the hypothesis that phyto-oestrogens exert oestrogen-like actions on bone cells through the IGF system. By increasing IGF-binding protein 4 proteolysis phyto-oestrogens may increase IGF bioavailability and induce osteoblast proliferation. Osteoblasts would, in turn, express transforming growth factor- $\beta 1$, which either directly or by an IGFbinding protein 3-mediated action would induce osteoclast apoptosis. Lorenzetti et al. (2002) have demonstrated the involvement of IGF-I, although the presence of osteoblasts was not required. The system used was a murine monocytemacrophage cell line (RAW264.7) that differentiates into osteoclasts in the presence of receptor activator nuclear factor $\kappa \mathrm{B}$ ligand. At $50 \mu \mathrm{M}$ genistein blocks cell proliferation, while the addition of IGF-I inhibits this effect. At physiological concentrations both IGF-I and phytooestrogens inhibit osteoclast differentiation in a similar way to oestradiol. High concentrations of genistein induce increased osteoclast differentiation, an effect that is further increased by the addition of IGF-I. Genistein reduces cell adhesion and stimulates apoptosis via inhibition of topoisomerase II (Gao \& Yamaguchi, 1999). Genistein $\left(10^{-5}-10^{-7} \mathrm{M}\right)$ inhibits the increase in glucose consumption and lactic acid production induced by parathyroid hormone or prostaglandin $\mathrm{E}_{2}$ in tissue culture (Yamaguchi \& Gao, 1998). S Lorenzetti (personal communication) cultured human peripheral blood mononuclear cells in vitro with soluble receptor activator nuclear factor $\kappa \mathrm{B}$ ligand and macrophage colony-stimulating factor. Preliminary results showed that zearalenone, as well as oestradiol, are able to inhibit the secretion of matrix metalloproteinases, which are responsible for bone resorption and known markers of osteoclast differentiation.

In vitro studies indicate that phyto-oestrogens such as genistein are able to stimulate osteoblastic activity and inhibit osteoclast formation and action at a range of concentrations $\left(10^{-5}-10^{-7} \mathrm{M}\right)$ consistent with the levels observed in human subjects after ingestion of genistein. In the study of Setchell et al. (2001) administration of a single bolus dose of $50 \mathrm{mg}$ genistein indicated that the concentration that gives a maximum response is 1.26 (SD 0.27) $\mu \mathrm{mol} / \mathrm{l}$.

Cell studies make a valuable contribution to the understanding of the mechanism of action of phyto-oestrogens and to the explanation of some of the in vivo observations. However, adequate characterisation of such models is required, particularly as far as the ER status is concerned.

\section{Effects of phyto-oestrogens on bone: animal models}

Coxam (2003) has recently reviewed twenty-two studies involving ovariectomised rats, six studies of other rat models (including male rats) one study of mice and two studies of ovariectomised monkeys. The studies, which used various doses, different phyto-oestrogen-rich products and 
purified compounds (soyabean, soya milk, soyabean protein, genistein, daidzein, rutine, zearalenone and ipriflavone, as well as several phyto-oestrogen-rich medications used in traditional medicine) and different end points (BMD, bone strength, bone mass, histomorphometry and bone formation and resorption markers), all showed an effect in rats (except in one case) but not in monkeys.

Mühlbauer \& Li (1999) have demonstrated that consumption of a variety of salad vegetables, herbs and cooked vegetables commonly found in the human diet can increase bone mineral content, mean cortical thickness and mineral density of trabecular bone in male rats, and they attributed this effect to flavanols.

Although when compared with ageing human bone the ovariectomised-rat model has limitations related to the characteristics of bone remodelling (bone growth slows down but does not completely stop in the ageing rat), it is a recognised model (Food and Drug Administration, 1994). This rat model is used in preclinical studies of bone quality, for comparison of foods and compounds and to establish mechanisms of action in the whole organism, particularly in relation to bone tissue composition, mechanical properties and bone tissue physiology.

The rat studies demonstrated the effects of vegetable flavanols on the thickness of bone trabeculae (Mühlbauer \& Li, 1999) and those of rutin (Molteni \& Coxam, 2001), soyabean isoflavone concentrate (Picherit et al. 2001), daidzein, glycitein (Ishida et al. 2000) and flaxseeds (Horcajada-Molteni et al. 2000) on femoral failure load. Soyabean protein increased bone formation in tibial periostal cortical bone of castrated rats (Hegsted et al. 1999).
Coxam (2003) concludes that ' $\ldots$ a substantial body of work in animal models was attained in the past few years, and has provided convincing data for significant improvements of bone mass or other endpoints following soy feeding.'

\section{Cross-sectional observations in human populations}

Several cross-sectional observations have been carried out in population groups consuming soyabean isoflavones, both in South-East Asian countries and in the Western world (Table 1). Only papers published in an extended form have been included in the review, so that details of the methodology can be appreciated. The studies differ widely in their specific objectives and methodologies. First, they targeted different population groups. Seven of the eleven studies examined were conducted in post-menopausal women, one in pre- and post-menopausal women and two in perimenopausal women. The sample size is also extremely variable, ranging from thirty to about 3000 . Second, most studies looked at the current intake of soyabean isoflavones using food-frequency questionnaires (FFQ; Tsuchida et al. 1999; Ho et al. 2001; Mei et al. 2001; Greendale et al. 2002) or weighed records (3-7d), and only Kritz-Silverstein \& Goodman-Gruen (2002) looked at the usual consumption of foods. Although lifelong exposure was seldom evaluated, ethnicity can be considered to be a relevant marker. In most cases estimates of isoflavone intake were obtained by applying food composition tables that mainly comprise soyabean-based foods (e.g. tofu and soya milk) or bean sprouts and soya sauce. However, soyabean is an ingredient

Table 1. Human observational studies on phyto-oestrogens and bone health

\begin{tabular}{|c|c|c|c|c|c|}
\hline Reference & $\begin{array}{l}\text { Menopausal } \\
\text { status }\end{array}$ & $\begin{array}{l}\text { No. of } \\
\text { subjects }\end{array}$ & $\begin{array}{l}\text { Ethnicity of } \\
\text { subjects }\end{array}$ & $\begin{array}{l}\text { Isoflavone } \\
\text { intake }(\mathrm{mg} / \mathrm{d})\end{array}$ & Outcome \\
\hline \multicolumn{6}{|l|}{ High-intake populations } \\
\hline Tsuchida et al. (1999) & Peri-menopausal & 995 & Japanese & & + Metacarpal BMD \\
\hline Horiuchi et al. (2000) & Post-menopausal & 85 & Japanese & $\begin{array}{l}12.6 \mathrm{~g} \text { soyabean } \\
\text { protein }\end{array}$ & $\begin{array}{l}\text { + BMD-LS; + urinary DPD; NS ALP, } \\
\text { osteocalcin }\end{array}$ \\
\hline Somekawa et al. (2001) & Post-menopausal & 478 & Japanese & $<35 v_{.}>65$ & + BMD-LS \\
\hline Ho et al. (2001) & Premenopausal & 132 & Hong Kong Chinese & 1.4 v. 15 & $+\mathrm{BMD}$ \\
\hline \multirow[t]{2}{*}{ Mei et al. (2001) } & Premenopausal & 293 & & 18 v. 47 & $\begin{array}{l}\text { Post-menopausal: + BMD-LS and Ward's } \\
\text { triangle; } \downarrow \text { PTH, osteocalcin, N-telopeptide }\end{array}$ \\
\hline & Post-menopausal & 357 & & & Premenopausal: NS \\
\hline Nagata et al. 2002 & Post-menopausal & 87 & Japanese & 32 & NS BMD NS-ALP \\
\hline Kim et al. 2002 & Post-menopausal & 75 & Korean & $20-150$ & $\begin{array}{l}\text { NS BMD; } \downarrow \text { enterolactone in osteoporotic } \\
\text { subjects }\end{array}$ \\
\hline \multicolumn{6}{|l|}{ Low-intake populations } \\
\hline Kardinaal et al. (1998) & Post-menopausal & 70 & Dutch & 0.35 & NS rate of bone loss \\
\hline Di Leo et al. (2002) & Post-menopausal & 30 & Italian & $0.35 ; 17.5$ & NS Tr BMD; To BMD; stress strain index \\
\hline Greendale et al. (2002) & Peri-menopausal & $\begin{array}{r}1003 \\
497 \\
200 \\
227\end{array}$ & $\begin{array}{l}\text { Caucasian } \\
\text { African-American } \\
\text { Chinese } \\
\text { Japanese }\end{array}$ & $\begin{array}{l}0.5-10.7 \mathrm{mg} \\
\text { genistein }\end{array}$ & $\begin{array}{l}\text { BMD-FN; BMD-LS in Japanese women } \\
\text { NS BMD in other ethnic groups }\end{array}$ \\
\hline $\begin{array}{l}\text { Kritz-Silverstein \& } \\
\text { Goodman-Gruen (2002) }\end{array}$ & Post-menopausal & 208 & American & $\begin{array}{l}0-13.9 \mathrm{mg} \\
\text { genistein }\end{array}$ & $\downarrow$ Lower urinary N-telopeptide \\
\hline
\end{tabular}

BMD, bone mineral density; BMD-LS, BMD at the lumbar spine; BMD-FN, BMD at the femoral neck; Tr BMD, trabecular BMD; To BMD, total BMD; DPD, deoxypyridinoline; ALP, alkaline phosphatase; PTH, parathyroid hormone; +, higher at higher intakes; $\downarrow$, lower at higher intakes; NS, no significant difference at higher intakes. 
of many industrial products and this factor is sometimes not recognised. Only in some cases (Kardinaal et al. 1998; Somekawa et al. 2001) were more objective measures of isoflavone intake, such as urinary isoflavones, obtained. The outcome variables measured were BMD at the lumbar spine, femoral neck or metacarpal and bone formation or resorption markers. Finally, only some of the studies controlled for confounding factors (age, height, weight, years since menopause, smoking, intake of $\mathrm{Ca}$ and other nutrients, alcohol consumption, HRT usage etc.). It is therefore difficult to attempt to pool the data from the different studies and a more qualitative evaluation is required.

Of the two studies conducted among premenopausal women, the first one, a 3-year prospective study conducted in 30-40-year-old women (Ho et al. 2001), reported significant differences $(P<0.05)$ in spinal BMD in the highest (mean $15 \mathrm{mg}$ isoflavones/d)- and lowest (mean $1.4 \mathrm{mg} / \mathrm{d}$ )-soyabean-intake groups, while the second study (Mei et al. 2001) reported no association between dietary phyto-oestrogen intake and BMD.

Among the studies of post-menopausal women, of the six studies conducted in countries with high isoflavone intake four indicated better bone health in the groups with the highest intake. Mei et al. (2001) found significant differences between the highest (mean $47.4 \mathrm{mg} / \mathrm{d}$ ) and lowest (mean $18.6 \mathrm{mg} / \mathrm{d}$ ) isoflavone intakes in the lumbar spine $\operatorname{BMD}\left(0 \cdot 820(\operatorname{SD} 0 \cdot 145)\right.$ v. $\left.0.771(\operatorname{SD~} 0 \cdot 131) \mathrm{g} / \mathrm{cm}^{2} ; P<0 \cdot 05\right)$ and Ward's triangle BMD $(0.450$ (SD 0.151) v. 0.415 (SD 0.142$\left.) \mathrm{g} / \mathrm{cm}^{2} ; P<0.05\right)$. Women with the highest isoflavone intake had significantly lower levels of serum parathyroid hormone, osteocalcin and urinary N-terminal telopeptides. Tsuchida et al. (1999) found an association between weekly $\mathrm{Ca}$ intake from soyabean and BMD of the metacarpal. Horiuchi et al. (2000) also found an association between soyabean protein intake and the $\mathrm{z}$ score of BMD. Somekawa et al. (2001) found that early post-menopausal women in the highest quartile of intake (mean $83.3 \mathrm{mg} / \mathrm{d}$ ) had $7.9 \%$ higher lumbar spine BMD than women in the lowest quartile of intake (mean $28.9 \mathrm{mg} / \mathrm{d}$ ). Two studies failed to find an association; there was no significant association between intake and BMD or alkaline phosphatase (Nagata et al. 2002), or between total urinary phytooestrogen excretion and BMD (Kim et al. 2002).

In the four studies conducted in populations with lower intakes no association was found between isoflavone intake and bone BMD or bone turnover, except in the subgroups with the highest lifelong intakes, i.e. Asian immigrants (Greendale et al. 2002; Kritz-Silverstein \& GoodmanGruen, 2002). In the study of Greendale et al. (2002) African-American and Caucasian women reported intakes of 0.5 and $1.4 \mathrm{mg}$ genistein/d respectively, while Kardinaal et al. (1998) reported urinary isoflavone levels indicative of an intake of $0.35 \mathrm{mg} / \mathrm{d}$ and the women on a typically 'Mediterranean' diet had intakes of $0.35 \mathrm{mg}$ total phytooestrogens/d (Di Leo et al. 2002).

\section{Intervention trials}

Human trials are probably the most indicative measure of the effect of phyto-oestrogens. Table 2 lists the main studies conducted so far in post-menopausal women. Again, studies

Table 2. Human intervention trials on phyto-oestrogens and bone health in post-menopausal women

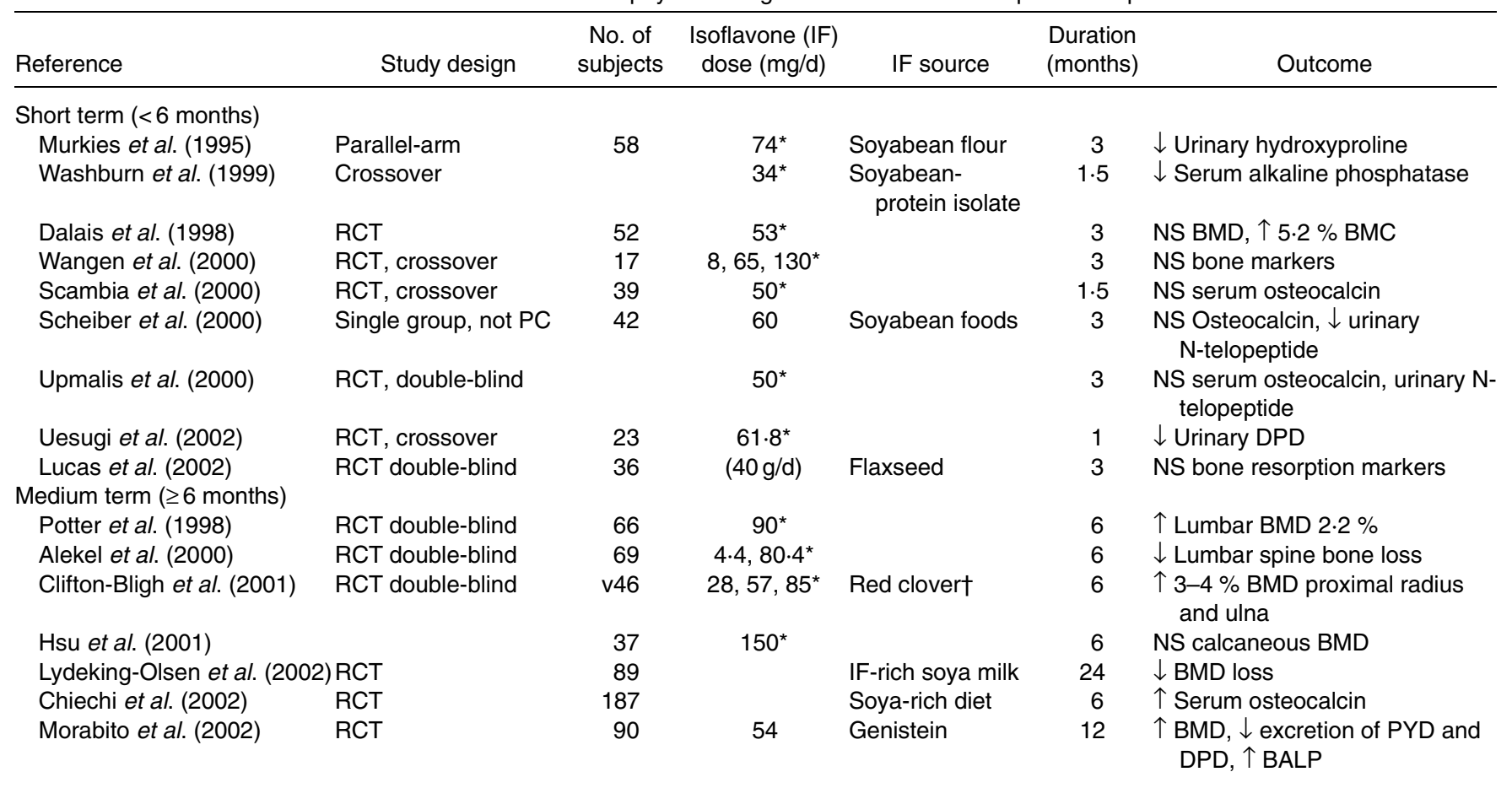

NS, difference not significant from baseline; $\uparrow$, increase from baseline; $\downarrow$, decrease from baseline; RCT, randomised controlled trial; PC, placebo controlled; BMD, bone mineral density; BMC, bone mineral content; DPD, deoxypyridinoline; PYD, pyridinoline; BALP, bone alkaline phosphatase.

*Total IF.

† Trifolium pratense. 
only appearing in abstract form that have not given details of the protocol have not been included, except one that has been quoted in an extended paper, because it is the only study that has achieved a 24-month period of supplementation (Lydeking-Olsen et al. 2002).

Seven of these studies were of $<6$ months duration. Murkies et al. (1995) recruited women who were 5-6 years post-menopausal and assigned them to a daily intake of either $45 \mathrm{~g}$ soyabean flour or $45 \mathrm{~g}$ wheat flour. After 3 months urinary hydroxyproline was increased in both groups, but significantly more in the wheat-flour group. Washburn et al. (1999) found that women given a soyabeanprotein isolate providing $34 \mathrm{mg}$ isoflavones/d had lower serum alkaline phosphatase levels than women given the same isolate with a lower isoflavone content. Dalais et al. (1998) conducted a 3-month randomised controlled trial (RCT) with fifty-two post-menopausal women who received diets containing soyabean (providing $53 \mathrm{mg}$ total isoflavones/d), linseed or wheat. A significant difference from baseline was observed only in the soyabean-diet group, with a $5 \cdot 2 \%$ increase in bone mineral content. Wangen et al. (2000) carried out a crossover RCT with seventeen postmenopausal women, each undertaking one of three 3-month periods with 8,65 or $130 \mathrm{mg}$ isoflavones/d. In the highisoflavone period the excretion of deoxypyridinoline and cross-linked C-telopeptides, both resorption markers, was lower than that in the baseline period, but the difference was not statistically significant. Scambia et al. (2000) conducted a RCT with thirty-nine post-menopausal women aged 2963 years, who were supplemented with $50 \mathrm{mg}$ total isoflavones/d for 6 weeks. Bone markers did not show significant changes in osteocalcin levels. Upmalis et al. (2000) found no difference for serum osteocalcin or urinary cross-linked N-telopeptides after 12 weeks of supplementation with $50 \mathrm{mg}$ genistein/d. Uesugi et al. (2002) conducted a RCT with twenty-three peri-menopausal women (age-range 40-62 years) for 4 weeks, and observed a reduction in bone resorption (urinary pyridinoline and deoxypyridinoline) in the group given $61.8 \mathrm{mg}$ total isoflavones/d. In another study (Lucas et al. 2002) postmenopausal women received a flaxseed supplement containing lignins, which had no effect on biomarkers of bone metabolism.

Seven more studies of $\geq 6$ months duration have been published, of which five were conducted for 6 months. Potter et al. (1998) carried out a double-blind placebocontrolled RCT with sixty-six post-menopausal women. In this study $90 \mathrm{mg}$ isoflavones/d induced a $2.2 \%$ increase in lumbar spine BMD compared with baseline. However, the group showing the effect had the lowest baseline BMD. Alekel et al. (2000) conducted a RCT with sixty-nine perimenopausal women comparing isoflavone intakes of 4 and $80 \mathrm{mg} / \mathrm{d}$ and showed a $1.28 \%$ reduction in lumbar spine BMD in the low-intake group, while the high-intake group was protected. Clifton-Bligh et al. (2001) performed a double-blind study of forty-six post-menopausal women receiving daily 28,57 or $85 \mathrm{mg}$ of a red clover (Trifolium pratense)-isoflavone preparation (Rimostil) containing genistein, daidzein, formononetin and biochanin. The two higher-intake groups showed an increase in BMD of 3-4\% at the proximal radius and ulna. Hsu et al. (2001) carried out a study of thirty-seven post-menopausal women receiving $150 \mathrm{mg}$ isoflavones/d. No effect was observed in calcaneal BMD. Chiechi et al. (2002) conducted a RCT with 187 postmenopausal women (age-range 39-60 years) comparing a soyabean-rich diet with HRT; the isoflavone intake is not clear from the report. There was an increase in serum osteocalcin levels and a non-significant reduction in

hydroxyproline excretion in the soyabean-diet group, while the group receiving HRT showed a significant reduction in hydroxyproline excretion. A reduction in trabecular BMD was observed in the control group, while the groups receiving the soyabean diet and HRT showed no significant reduction.

Two studies were carried out for $>6$ months. In the study of Morabito et al. (2002) ninety post-menopausal women were randomly assigned to receive $54 \mathrm{mg}$ genistein/d, HRT or a placebo and followed for 12 months. In the groups receiving genistein and HRT they observed an increase in BMD at the femoral neck, Ward's triangle and lumbar spine, and reduced pyridinoline and deoxypyridinoline excretion, at 6 and 12 months. Interestingly, they also observed increased serum bone alkaline phosphatase and osteocalcin levels at 6 and 12 months in the genistein-treated group. The study of Lydeking-Olsen et al. (2002) was carried out for 24 months, but the findings are unfortunately only available in an abstract. Some data have also been published in Setchell et al. (2002a). Eighty-nine postmenopausal women (age-range 41-75 years) were randomly assigned to receive isoflavone-rich soya milk $(100 \mathrm{mg} / \mathrm{d})$ and natural transdermal progesterone $(25 \mathrm{mg} / \mathrm{d})$ individually or in combination, a placebo and a progesterone-free cream. Lumbar spine BMD and bone mineral content did not differ from baseline in the groups receiving soya-milk $(+1 \cdot 1$ and $+2.0 \%$ respectively) and transdermal-progesterone $(-1 \cdot 1$ and $+0.4 \%$ respectively), but there was a loss in both variables in the groups receiving the placebo $(-4.2$ and $-4.3 \%$ respectively) and the progesterone-free cream $(-2 \cdot 8$ and $-2.4 \%$ respectively). There were no significant changes in femoral neck BMD or bone mineral content in any of the groups.

Again, it is difficult to pool the data from the different studies. First there was an inconsistency in the objectives of the studies. Valtueña et al. (2003) suggested that studies should address: the bone-sparing effect in post-menopausal women; the selection of compounds, dose and mode of delivery; the size of the effect and its sustainability; the timing of the intervention (before/after menopause); the mechanisms of action (reduced bone breakdown, increased formation, or both); the sites of the skeleton receiving the largest benefit; the relevance in terms of fracture risk reduction. These factors have not been addressed by most of the studies. The main weakness of human trials is, however, their duration. Long-term studies that cover a minimum of one remodelling cycle (30-80 weeks) should be conducted. In fact, many studies have been conducted for other purposes, e.g. cardiovascular disease or menopausal symptom relief.

Despite methodological weaknesses and inconsistencies, the conclusion that can be drawn from human studies is indicative of a positive effect of soyabean isoflavones on bone health. In observational studies the results for post- 
menopausal women indicate that intake levels similar to those observed in South-East Asian populations (mean $50 \mathrm{mg}$ isoflavone/d) allow the preservation of bone mass in menopause, possibly through a decrease in bone resorption. All studies have looked at ethnic groups with lifelong intakes, and it is difficult to use observational data to obtain indications for Western populations. Among the intervention trials, short-term studies are not consistent in indicating an impact on either BMD or bone turnover. Among the longer-term studies, six of the seven studies showed an effect, although moderate. The only negative study (Hsu et al. 2001) was underpowered.

\section{Public health implications and unresolved issues}

Research in the field is progressing rapidly, as is consensus among the scientists. The National Institutes of Health (2000) Consensus Conference stated, 'There is a great deal of public interest in natural estrogens, particularly plantderived phytoestrogens. These compounds have weak estrogen-like effects, and although some animal studies are promising, no effects on fracture reduction in humans have been shown'. Only 3 years later another panel of experts convened by the UK Food Standard Agency (2002) concluded that 'Clinical data on the effects of phytoestrogens on bone density are limited but results of short-term human studies suggest small protective effects in the lumbar spine. The data for protective effects at other sites are equivocal'. Since this latter statement only the paper by Morabito et al. (2002) has made a further contribution, but little can be added, although two major trials are currently being undertaken (one in Europe (the PHYTOS project) and one in the USA (the OPUS project)). There is, however, still a knowledge gap. Unresolved issues include: the optimal dose compatible with safety; the individual differences in response related to diet and genotypes; the duration of exposure; lifelong exposure as opposed to post-menopausal exposure only. Furthermore, the relative biological effects of phyto-oestrogens other than isoflavones (lignans, resorcylic acid lactones, flavanols, coumestans) that are also present in European diets need to be evaluated.

If an effect of phyto-oestrogen on bone health in menopause is demonstrated, then the question arises of how to deliver the compounds, i.e. with products containing high amounts (e.g. soyabean), with supplements or with enriched foods. There is a large difference in the dietary intakes of soyabean isoflavones between South-East Asia and the Western World. In USA and Europe it is of the order of $1 \mathrm{mg} / \mathrm{d}$ (Kuhnau, 1976). van Erp-Baart et al. (2003) obtained an estimate of isoflavone intake within the framework of the Vegetal Estrogens in Nutrition and the Skeleton (VENUS) project. They used a purposely-developed database and then applied it to the national dietary intakes obtained in Republic of Ireland, Italy, The Netherlands and the UK. The intake in Europe is also of the order of $1 \mathrm{mg} / \mathrm{d}$, and $\leq 6-10 \mathrm{mg} / \mathrm{d}$ among consumers of soyabean foods. A UK study of a small group of vegetarians ( $n$ 35) pointed to an intake of $12 \mathrm{mg}$ genistein and daidzein/d (Food Standards Agency, 2002). In South-East Asia isoflavone intake is on average $50 \mathrm{mg} / \mathrm{d}$, but it can also be as high as $100 \mathrm{mg} / \mathrm{d}$. Achieving such an intake would involve substantial changes in Western dietary habits, even beyond the current intake of some population groups (i.e. vegetarians).

The second option is the enrichment of commonly-used Western foods with soyabean isoflavones or with other phyto-oestrogens. In order to establish the most appropriate fortification levels, a decision should be reached on an appropriate dose. The US Consensus Panel (2000, unpublished results), reviewing the available literature at the time, concluded that $40-60 \mathrm{mg}$ aglycones/d are required for cardiovascular risk reduction, $60 \mathrm{mg}$ aglycones/d for relief of menopause symptoms, $90 \mathrm{mg}$ aglycones/d to achieve bone health benefits and 50-110 mg aglycones/d for cancer prevention. Thus, the panel concluded that the recommended isoflavone intake might range from 60 to $100 \mathrm{mg}$ aglycones/d, with the lower dose considered as 'reasonable and responsible'. Since the diet contains negligible amounts of isoflavones, they would have to be added. Furthermore, the level of fortification would have to be low enough to prevent the intake of excessively high doses.

The third option would be to consider whether other compounds already present in Mediterranean food might be suitable for use in replacing soyabean isoflavones in relation to their bone-sparing effect. Hertog et al. (1997) estimated the intake of flavonols and flavones in The Netherlands to be $23 \mathrm{mg} / \mathrm{d}$, and Leth \& Justesen (1998) estimated the intake of flavonols, flavones and flavanones in Denmark to be $28 \mathrm{mg} / \mathrm{d}$. In Southern European countries this estimate might be even higher, since the intake of fruit and vegetables is approximately $500 \mathrm{~g} / \mathrm{d}$ for Italy, France and Spain. It is not known whether the effects of the different compounds are synergistic or whether they compete for mechanisms of action, or indeed cooperate in the modulation of such response mechanisms. However, the impact of high intake levels of other flavonoids should be considered and the recommended doses of isoflavone adjusted accordingly.

\section{References}

Alekel DL, Germain AS, Peterson CT, Hanson KB, Steward JW \& Toda T (2000) Isoflavone-rich soy protein isolate attenuate bone loss in the lumbar spine of perimenopausal women. American Journal of Clinical Nutrition 72, 844-852.

Anderson JJB, Adlercreutz H, Barnes S, Bennink MR, Clarkson T, Jeffrey E, Kurzer MS, Murphy P, Setchell K, Weaver CM \& Hasler CM (2000) Appropriate isoflavone food fortification levels: results of a consensus conference. Experimental Biology 2000, San Diego, CA: Publishers?

Batra GS, Hainey L, Freemont AJ, Andrew G, Saunders PTK, Hoyland JA \& Braidman IP (2003) Evidence for cell-specific changes with age in expression of oestrogen receptor (ER) $\alpha$ and $\beta$ in bone fractures from men and women. Journal of Pathology 200, 65-73.

Berrino F, Secreto G, Bellati C, Camerini E, Pala V, Panico S, Allegro G \& Kaaks R (2001) Reducing bio-available sex hormones through a comprehensive change in dietary composition: the DIANA randomised trial. Cancer Epidemiology Biomarkers and Prevention 10, 25-33.

Bonnelye E, Kung V, Laplace C, Galson DL \& Aubin JE (2002) Estrogen receptor-related receptor $\alpha$ impinges on the estrogen 
axis in bone: potential function in osteoporosis. Endocrinology 143, 3658-3670.

Braidman IP, Davenport LK, Carter DH, Selby PL, Mawer EB \& Freemont AJ (1995) Preliminary in-situ identification of estrogen target cells in bone. Journal of Bone and Mineral Research 10, 74-80.

Braidman IP, Hainey L, Batra G, Selby PL, Saunders PTK \& Hoyland JA (2001) Localization of estrogen receptor beta protein expression in adult human bone. Journal of Bone and Mineral Research 16, 214-220.

Camper-Kirby D, Welch S, Walker A, Shiraishi I, Setchell KDR, Schaefer E, Kajstura J, Anversa P \& Sussman MA (2001) Myocardial Akt activation and gender increased nuclear activity in females versus males. Circulation Research 88, 1020-1027.

Chiechi LM, Secreto G, D'Amore M, Fanelli M, Venturelli E, Cantatore F, Valerio T, Laselva G \& Loizzi P (2002) Efficacy of a soy rich diet in preventing postmenopausal osteoporosis: the Menfis ranomised trial. Maturitas 42, 295-300.

Clifton-Bligh PB, Barber RJ, Fulcher GR, Nery ML \& Moreton T (2001) The effect of isoflavones extracted from red clover (Rimostril) on lipid and bone metabolism. Menopause 8, 259-265.

Cotroneo MS, Wang J, Eltoum IA \& Lamartiniere CA (2001) Sex steroid receptor regulation by genistein in the prepubertal rat uterus. Molecular and Cellular Endocrinology 173, 135-145.

Coxam V (2003) Prevention of osteopaenia by phyto-oestrogens: animal studies. British Journal of Nutrition 89, Suppl. 1, S75-S85.

Dalais FS, Rice GE, Wahlqvist ML, Grehan M, Murkies AL, Medley G, Ayton R \& Strauss BJ (1998) Effects of dietary phytoestrogens in postmenopausal women. Climacteric 1, 124-129.

Di Leo C, Tarolo GL, Bestetti A, Tagliabue L, Del Sole A, Aliberti G Cestaro B \& Pepe L (2000) Osteoporosi e fitoestrogeni: valutazione della densita minerale ossea mediante Tomografia Computerizzata quantitativa periferica nelle donne lattoovovegetariane nella premenopausa (Osteoporosis and phytoestrogens: an assessment of bone mineral density via quantitative peripheral computed tomography in milk-egg-vegetarian women in the premenopause). Radiologica Medica (Torino) 99, 250-257.

Eden JA (1998) Phytoestrogen study design. Climacteric 1, 243-244.

Food and Drug Administration (1994) Guidelines for Preclinical and Clinical Evaluation of Agents Used in the Prevention or Treatment of Postmenopausal Osteoporosis. Rockville, MD: FDA.

Food Standards Agency (2002) Report of the COT Working Group on Phytoestrogens; available at http://www.food.gov.uk/ multimedia/pdfs/phytoestrogenreport.pdf

Fotsis T, Pepper M, Adlercreutz H, Fleischman G, Hase T, Montesano R \& Schweigerer L (1993) Genistein, a dietaryderived inhibitor of in vitro angiogenesis. Proceedings of the National Academy of Sciences USA 90, 2690-2694.

Frey RS \& Singletary KW (2003) Genistein activates p38 mitogenactivated protein kinase, inactivates ERK1/ERK2 and decreases Cdc25C expression in immortalized human mammary epithelial cells. Journal of Nutrition 133, 226-231.

Gao YH \& Yamaguchi M (1999) Inhibitory effect of genistein on osteoclast-like cell formation in mouse marrow cultures. Biochemical Pharmacology 58, 767-772.

Greendale GA, Fitzgerald G, Huang MH, Sternfeld B, Gold E, Seeman T, Sherman S \& Sowers M (2002) Dietary soy isoflavones and bone mineral density: results from the study of women's health across the nation. American Journal of Epidemiology 155, 746-754.

Guo TL, McCay JA, Zhang LX, Brown RD, You L, Karrow NA, Germolec DR \& Ehite KL Jr (2001) Genistein modulates immune responses and increases host resistance to B16F10 tumor in adult female B6C3F1 mice. Journal of Nutrition 131, $3251-3258$
Hall JM, Couse JF \& Korach KS (2001) The multifaceted mechanisms of estradiol and estrogen receptor signaling. Journal of Biological Chemistry 276, 36869-36872.

Han DH, Denison MS, Tachibana H \& Yamada K (2002) Relationship between estrogen receptor-binding and estrogenic activities of environmental estrogens and suppression by flavonoids. Bioscience Biotechnology Biochemistry 66, 1479-1487.

Hegsted M, Warner S, Heaton S, Bowman B \& Miller SC (1999) Soy diet increases tibial cortical bone formation in ovariectomized retired breeder rats. Journal of Bone and Mineral Research 14, S531.

Hertog MGL, Feskens EJM \& Kromhout D (1997) Antioxidant flavonols and coronary heart disease risk: ten year follow-up of the Zutphen Elderly Study. Lancet 349, 699.

Ho SC, Chan SG, Yi Q, Wong E \& Leung PC (2001) Soy intake and the maintenance of peak bone mass in Hong Kong Chinese women. Journal of Bone and Mineral Research 16, 1363-1369.

Horcajada-Molteni MN, Crespy V, Coxam V, Davicco MJ, Remesy C \& Barlet JP (2000) Rutine inhibits ovariectomyinduced osteopenia in rats. Journal of Bone and Mineral Research 15, 2251-2258.

Horiuchi T, Onouchi T, Takahashi M, Ito H \& Orimo H (2000) Effect of soy protein on bone metabolism in postmenopausal Japanese women. Osteoporosis International 11, 721-724.

Hsu C-S, Shen WW, Hsueh YM \& Yeh SL (2001) Soy isoflavone supplementation in postmenopausal women. Journal of Reproductive Medicine 42, 221-226.

Hughes DE, Dai A, Tiffee JC, Li HH, Mundy GR \& Boyce BF (1996) Estrogen promotes apoptosis of murine osteoclasts mediated by TGF $\beta$. Nature Medicine 2, 1132-1136.

Hunter I, McGregor DP \& Robins SP (2001) Caspase-dependent cleavage of cadherins and catenins during osteoblast apoptosis. Journal of Bone and Mineral Research 16, 466-477.

Ishida H, Uesugi T, Toda T \& Tsuji K (2000) Effect of soy isoflavones, daidzein, genistein and glycitein on bone loss and lipid metabolic pathway in ovariectomized rats. Journal of Nutrition 130, Suppl., 685S.

Kardinaal AFM, Morton MS, Bruggermann-Rotgans IEM \& van Beresteijn ECH (1998) Phytoestrogen excretion and rate of bone loss in postmenopausal women. European Journal of Clinical Nutrition 52, 850-855.

Kim MK, Chung BC, Yu VY, Nam JH, Lee HC, Huh KB \& Lim SK (2002) Relationships of urinary phyto-oestrogen excretion to BMD in postmenopausal women. Clinical Endocrinology 56, 321-328

Kritz-Silverstein D \& Goodman-Gruen DL (2002) Usual dietary isoflavone intake, bone mineral density, and bone metabolism in postmenopausal women. Journal of Womens' Health and Gender Based Medicine 11, 69-78.

Kuhnau J (1976) The flavonoids: a class of semi-essential food components: their role in human nutrition. World Review of Nutrition and Dietetics 24, 117-191.

Kuiper GGJM, Carlsson B, Grandien K, Enmark E, Haggblad J, Nilsson S \& Gustafsson JA (1997) Comparison of the ligand binding specificity and transcript tissue distribution of estrogen receptors alpha and beta. Endocrinology 138 , $863-870$

Lamartiniere CA, Cotroneo MS, Fritz WA, Wang J, Mentor-Marcel R \& Elgavish A (2002) Genistein chemoprevention: Timing and mechanisms of action in murine mammary and prostate. Journal of Nutrition 132, 552S-558S.

Leth T \& Justesen U (1998) Analysis of flavonoids in fruits, vegetables and beverages by HPCL-UV and LC-MS and estimation of the total daily flavonoid intake in Denmark. In Polyphenols in Food, pp. 39-40. [R Amado, H Andersson, S Bardocz and S Serra, editors]. Luxembourg: Official Publications of the European Communit. 
Lieberherr M, Cournot G \& Robins SP (2003) Guidelines for using in vitro methods to study the effects of phyto-oestrogens on bone. British Journal of Nutrition 89, Suppl. 1, S59-S73.

Lorenzetti S, Germani D, Farini D, Paterno A, Branca F \& Cianfarani S (2002) Inhibitory effects of $17 \beta$-estradiol, phytoestrogens and IGF-I peptides on murine and human osteoclastogenesis. Hormone Research 58, Suppl. 2, 112.

Lucas EA, Wild RD, Hammond LJ, Khalil DA, Juma S, Daggy BP, Stoecker BJ \& Arjmandi BH (2002) Flaxseed improves lipid profile without altering biomarkers of bone metabolism in postmenopausal women. Journal of Clinical Endocrinology and Metabolism 87, 1527-1532.

Lydeking-Olsen E, Jensen J-BE, Setchell KDR, Damhus M \& Jensen TH (2002) Isoflavone-rich soymilk prevents bone-loss in the lumbar spine of postmenopausal women. A 2 year study. Journal of Nutrition 132, 581S.

Matsukawa Y, Marui N, Sakai T, Satomi Y, Yoshida M, Matsumoto K, Nishino H \& Aoike A (1993) Genistein arrests cell cycle progression at G2M. Cancer Research 53, 1328-1331.

Mazur WM, Uehara M, Wahala K \& Adlercreutz H (2000) Phytooestrogen content of berries, and plasma concentrations and urinary excretion of enterolactone after a single strawberry-meal in human subjects. British Journal of Nutrition 83, 381-387.

Mei J, Yeung SSC \& Kung AWC (2001) High dietary phytoestrogen intake is associated with higher bone mineral density in postmenopausal but not premenopausal women. Journal of Clinical Endocrinology and Metabolism 86, 5217-5221.

Molteni \& Coxam V (2001)

Morabito N, Crisafulli A, Vergara C, Gaudio A, Lasco A, Frisina N, D'Anna R Corrado F, Pizzoleo MA, Cincotta M, Altavilla D, Ientile R \& Squadrito F (2002) Effects of genistein and hormonereplacement therapy on bone loss in early postmenopausal women: a randomized double-blind placebo-controlled study. Journal of Bone and Mineral Research 17, 1904-1911.

Morton MS, Matos-Ferreira A, Abranches-Monterio L, Correia R, Blacklock N, Chan PSF, Cheng C, Lloyd S, Chieh-Ping W \& Griffiths K (1997) Measurement and metabolism of isoflavonoids and lignans in human male. Cancer Letters 114, 145-151.

Murkies AL, Lombard C, Strauss BJG, Wilcox G, Burger HG \& Morton MS (1995) Dietary flour supplementation decreases post-menopausal hot flushes: effect of soy and wheat. Maturitas 21, 189-195.

Mühlbauer RC \& Li F (1999) Effects of vegetables on bone metabolism. Nature 401, 343-344.

Nagata C, Shimizu H, Takami R, Hayashi M, Takeda N \& Yasuda $\mathrm{K}$ (2002) Soy product intake and serum isoflavonoid and estradiol concentrations in relation to bone mineral density in postmenopausal Japanese women. Osteoporosis International 13, 200-204.

National Institutes of Health (2000) National Institutes of Health Consensus Development Conference statement. Osteoporosis Prevention, Diagnosis, and Therapy, vol. 17. Bethesda, MD: National Institutes of Health.

Nilsson S, Makela S, Treuter E, Tujague M, Thomsen J, Andersson G, Enmark E, Pettersson K, Warner M \& Gustafsson JA (2001) Mechanisms of estrogen action. Physiological Reviews 81, 1535-1565.

Oreffo RO, Kusec V, Virdi AS, Flanagan AM, Grano M, Zambonin-Zallone A \& Triffitt JT (1999) Expression of estrogen receptor-alpha in cells of the osteoclastic lineage. Histochemistry Cell Biology 111, 125-133.

Paech K, Webb P, Kuiper GGJM, Nilsson S, Gustafsson JA, Kushner PJ \& Scalan TS (1997) Differential ligand activation of estrogen receptors ER $\alpha$ and ER $\beta$ at AP1 sites. Science 277, 1508-1510.

Picherit C, Bennetau-Pelissero C, Chanteranne B, Lebecque P, Davicco MJ, Barlet JP \& Coxam V (2001) Soybean isoflavones dose-dependently reduce bone turnover but do not reverse established osteopenia in adult ovariectomized rats. Journal of Nutrition 131, 723-728.

Pike AC, Brzozowski AM, Hubbard RE, Bonn T, Thorsell AG, Engstrom O, Ljunggren J, Gustafsson JA \& Carlquist M (1999) Structure of the ligand-binding domain of oestrogen receptor beta in the presence of a partial agonist and a full antagonist. EMBO Journal 18, 4608-4618.

Potter SM, Baum JA, Teng H, Stillman RJ, Shay NF \& Erdman JW (1998) Soy protein and isoflavones: effects on blood lipids and bone density in postmenopausal women. American Journal of Clinical Nutrition 68, 1375S-1379S.

Rassi CM, Lieberherr M, Chaumaz G, Pointillart A \& Cournot G (2002) Down-regulation of osteoclast differentiation by daidzein via caspase 3. Journal of Bone and Mineral Research 17, 630-638.

Rickard DJ, Monroe DG, Ruesink TJ, Khosla S, Riggs BL \& Spelsberg TC (2003) Phytoestrogen genistein acts as an estrogen agonist on human osteoblastic cells through estrogen receptors alpha and beta. Journal of Cell Biochemistry 89, 633-646.

Ross JA \& Kasum CM (2002) Dietary flavonoids: bioavailability, metabolic effects, and safety. Annual Review of Nutrition 22, 19-34.

Rowland I, Faughnan M, Hoey L, Wahala K, Williamson G \& Cassidy A (2003) Bioavailability of phyto-oestrogens. British Journal of Nutrition 89, Suppl. 1, S45-S58.

Saarinen N, Joshi SC, Ahotupa M, Li X, Ammala J, Makela S \& Santti R (2001) No evidence for the in vivo activity of aromatase-inhibiting flavonoids. Journal of Steroid Biochemistry and Molecular Biology 78, 231-239.

Scambia G, Mango D, Signorile PG, Angeli RA, Palena C Bombardelli E, Morazzoni P, Riva A \& Mancuso S (1999) Clinical effects of a standardised soy extract in postmenopausal women: a pilot study. Menopause 6, 233-241.

Scheiber MD, Liu JH, Subbiah MTR, Rebar RW \& Setchell KDR (2000) Dietary soy isoflavones favorably influence lipids and bone turnover in healthy postmenopausal women. Journal of Nutrition 130, 668S.

Setchell KDR, Brown NM, Desai P, Zimmer-Nechemias L, Wolfe BE, Brashear WT, Kirschner AS, Cassidy A \& Heubi JE (2001) Bioavailability of pure isoflavones in healthy humans and analysis of commercial soy isoflavone supplements. Journal of Nutrition 131, 1362S-1375S.

Setchell KD, Brown NM \& Lydeking-Olsen E (2002a) The clinical importance of the metabolite equol - a clue to the effectiveness of soy and its isoflavones. Journal of Nutrition 132, 3577-3584.

Setchell KDR, Brown NM, Zimmer-Nechemias L, Brashear WT, Wolfe BE, Kirschner AS \& Heubi JE (2002b) Evidence for lack of absorption of soy isoflavone glycosides in humans, supporting the crucial role of intestinal metabolism for bioavailability. American Journal of Clinical Nutrition 76, 447-453.

Setchell KDR, Zimmer-Nechemias L, Cai J \& Heubi JE (1998) Isoflavone content of infant formulas and the metabolic fate of those phytoestrogens in early life. American Journal of Clinical Nutrition 68, 1453S-1461S.

Somekawa Y, Chiguchi M, Ishibashi T \& Aso T (2001) Soy intake related to menopausal symptoms, serum lipids, and bone mineral density in postmenopausal Japanese women. Obstetrics and Gynecology 97, 109-115.

Srivastava S, Weitzmann MN, Kimble RB, Rizzo M, Zahner M, Milbrandt J, Ross FP \& Pacifici R (1998) Estrogen blocks MCSF gene expression and osteoclast formation by regulating phosphorylation of Egr-1 and its interaction with Sp-1. Journal of Clinical Investigation 102, 1850-1859.

Tsuchida K, Mizushima S, Toba M \& Soda K (1999) Dietary soybeans intake and bone mineral density among 995 middleaged women in Yokohama. Journal of Epidemiology 9, 14-19. 
Uesugi T, Fukui Y \& Yamori Y (2002) Beneficial effects of soybean isoflavone supplementation on bone metabolism and serum lipids in postmenopausal Japanese women: a four-week study. Journal of the American College of Nutrition 21, 97-102.

Upmalis DH, Lobo R, Bradley L, Warren M, Cone FL \& Lamia CA (2000) Vasomotor symptom relief by soy isoflavone extract tablets in postmenopausal women: a multicenter, double blind, randomized, placebo-controlled study. Menopause 7, 236-242.

Valtueña S, Cashman K, Robins SP, Cassidy A, Kardinaal A \& Branca F (2003) Investigating the role of natural phytooestrogens on bone health in postmenopausal women. British Journal of Nutrition 89, Suppl. 1, S87-S99.

van Erp-Baart A-MJ, Brants HAM, Keily M, Mulligan A, Turrini A, Sermoneta C, Kilkkinen A \& Valsta LM (2003) Isoflavone intake in four different European countries: the VENUS approach. British Journal of Nutrition 89, Suppl. 1, S25-S30.

Wangen KE, Duncan AM, Merz-Demlow BE, Xu X, Marcus R, Phipps WR \& Kurzer MS (2000) Effects of soy isoflavones on markers of bone turnover in premenopausal and postmenopausal women. Journal of Clinical Endocrinology and Metabolism 85, 3043-3048.

Washburn S, Burke GL, Morgan T \& Anthony M (1999) Effect of soy protein supplementation on serum lipoproteins, blood pressure, and menopausal symptoms in perimenopausal women Menopause 6, 7-13.

Writing Group for the Women's Health Initiative Investigators (2002) Risks and benefits of estrogen plus progesterone in healthy post-menopausal women. Journal of the American Medical Association 288, 321-333.

Yamaguchi M \& Gao YH (1997) Anabolic effect of genistein on bone metabolism in the femoral-metaphyseal tissues of elderly rats is inhibited by the anti-estrogen tamoxifen. Research in Experimental Medicine 197, 101-107.

Yamaguchi M \& Gao YH (1998) Anabolic effect of genistein and genistin on bone metabolism in the femoral-metaphyseal tissues of elderly rats: the genistein effect is enhanced by zinc. Molecular and Cellular Biochemistry 178, 377-82.

Yamaguchi M \& Sugimoto E (2000) Stimulatory effect of genistein and daidzein on protein synthesis in osteoblastic MC3T3-E1 cells: activation of aminoacyl-tRNA synthetase. Molecular and Cellular Biochemistry 214, 97-102.

Zand RS, Jenkins DJ \& Diamandis EP (2000) Steroid hormone activity of flavonoids and related compounds. Breast Cancer Research and Treatment 62, 35-49. 